\title{
THE ECOLOGY OF MELANISM IN YELLOW-BELLIED Marmots OF GRAND Teton National PARK: A SUMMARY OF 1994 AND 1995
}

\author{
GEORGE MONTOPOLI $\uparrow$ NICK VISSER $\uparrow$ STATISTICS \\ HENRY HARLOW $\uparrow$ DEPARTMENT OF ZOOLOGY AND PHYSIOLOGY \\ UNIVERSITY OF WYOMING † LARAMIE
}

\section{$\uparrow \quad$ ABSTRACT}

Melanism (black fur coloration) in the yellow-bellied marmot, Marmota flaviventris, is encountered uniquely in the Teton Range in northwest Wyoming. During the summers of 1994 and 1995, several aspects involving marmots and melanism were investigated, including the affect of human impact on the incidence of melanism, spatial implications of melanism, differential survival rates of melanistic and non-melanistic phenotypes, and temporal implications. Results suggest that the presence of humans is not related to the incidence of melanism when all surveyed areas of Grand Teton National Park are included in the analysis. However, when only those areas involving high human use and negligible human use are analyzed, then both the total number of marmots observed, and the proportion of melanistic marmots, are significantly higher in high human use areas. Differential survival rates of melanistic and nonmelanistic phenotypes were observed for both 1994 and 1995 when comparing the proportions of marmots corresponding to the different age classes (juveniles, subadults, and adults) for each pelage type (normal, melanistic, and other). Although 1994 and 1995 differed considerably with respect to the climate, only minute differences were observed in the proportions of the different pelage types and age groupings for the two years. Several interesting behaviors were documented including arboreal
\end{abstract}

activity, resistance to snow exposure, tunneling in ice and under rock, thermoregulation by conduction, and kissing and paw play as a means of communication.

\section{$\downarrow \quad$ INTRODUCTION}

The biology of melanism in the yellowbellied marmot (Marmota flaviventris) found in Grand Teton National Park (GTNP) may provide an informative model of evolution in an environment altered by human activities. Melanism in the yellow-bellied marmot has been documented only in the Teton Range (Fryxell 1928, Murie 1934, Armitage 1961), while melanism has gone to fixation in the Marmota vancouverensis of Vancouver Island (K. Armitage, pers. comm., May, 1994). Although melanism is fairly common in other sciurids (Kiltie 1989), neither the functional significance of melanism, nor the factors that affect temporal and spatial variation in its expression in marmot populations have been investigated. In this paper, we will investigate several significant findings related to melanism during two summers of research in GTNP. These findings include: 1) melanism and human impact; 2) spatial implications; 3) differential survival of marmots with melanistic and non-melanistic pelage; and 4) temporal implications. 


\section{MELANISM AND HUMAN IMPACT}

The yellow-bellied marmot in the Tetons may present an example of evolution influenced by humans. Melanistic pelage is believed to provide an adaptive advantage to marmots under specific environmental conditions. In a bioenergetics study, Kilgore (1972) suggested that marmots utilize solar energy to help maintain body temperature, and thus conserve metabolic energy. In avian species, Walsberg et al. (1978) defined conditions under which a thermoregulatory advantage could be achieved by dark plumage. Melanistic pelage in marmots may also present a thermoregulatory advantages which could enhance survival.

On the other hand, melanism in marmots may be associated with some disadvantageous aspects. For example, yellow-bellied marmots are subject to predation by birds, coyotes, and various mustelids (Craighead, 1951; Travis and Armitage 1972; Armitage 1982). While three-fourths of marmots above-ground behavior is devoted to exposed sunning, only a portion of this time is allotted to alert watching for predators (Travis and Armitage 1972; Montopoli \& Visser, pers. obs., 1994-95), which makes them highly vulnerable to attack. The Teton terrain typically is light-colored so that melanistic marmots may be more visible to predators than their normal-pelaged conspecifics. A similar observation was made on the Vancouver marmot (Swarth 1912).

However, in the presence of high densities of backcountry hikers and climbers, predation on melanistic marmots may be reduced because of the disturbance humans present to predators. If predators, especially avian ones, are more affected by human disturbance than are the marmots, then predation on marmots near areas of high human use could be lower than elsewhere. This would result in a higher incidence of the melanistic phenotype since it would be selected for due to its thermoregulatory advantages. We hypothesize that the lower predation risk, as a result of-human presence, would result in higher rates of melanism near areas with the greatest amount of human activity.

\section{SPATIAL IMPLICATIONS}

During surveys in GTNP, marmot encounters were greater near trails, and only rarely documented greater than $300 \mathrm{~m}$ from the trail. This was attributable to: 1) marmots near trails have habituated to humans, while those distant from trails have not, and they tend to hide; or 2) marmots receive a food reward near trails and/or 3) marmots near trails benefit from reduced predation pressure due to human presence.

Surveys into remote areas of GTNP where humans seldom venture have resulted in very few marmot sightings. We hypothesize that, when compared to areas of high human use, areas of low human use will exhibit: 1) fewer marmots in general; and 2) fewer melanistic marmots.

\section{DIFFERENTIAL SURVIVAL OF MELANISTIC AND NON-MELANISTIC PHENOTYPES}

During the study, differential survival of age categories (juveniles, subadults, and adults) was examined for animals with different pelage types (normal, melanistic, and other). We hypothesize that the proportion of marmots with a specified fur type would be approximately the same across all age categories. For example, if we were to observe that approximately $20 \%$ of the marmots born in a given year were melanistic, then if there was no differential mortality we would expect approximately $20 \%$ of the subadults and adults in the population to also be melanistic.

\section{TEMPORAL IMPLICATIONS}

Climatic conditions, especially snow level at higher altitudes $(>2000 \mathrm{~m})$, differed dramatically in 1994 and 1995 . While 1994 was characterized as a somewhat dry year, 1995 was characterized by late, heavy snowfalls that left a deep layer of snow throughout the Teton Range. We hypothesized a high marmot mortality and limited reproductive success, with marked changes in population dynamics for 1995, when compared to 1994 .

In addition, Armitage found that in a 1959 survey about $23.42 \%(n=111)$ of the marmots he observed were melanistic. We compared these data with our 1995-96 study to examine temporal fluctuations in the proportion of melanism.

\section{METHODS}

Survey points were chosen in canyons of GTNP which represented likely marmot habitat. Locations that were surveyed included Granite 
Canyon, Death Canyon, Alaska Basin, Avalanche Canyon, Garnet Canyon, Surprise, Amphitheater and Delta Lakes, Cascade Canyon, Hanging Canyon, Paintbrush Canyon, Grizzly Bear Lake area, Taggart Lake burn area, Beaver Creek Boneyard, Climber's Ranch and Highland's Residential Area. Two types of survey techniques were applied: stationary and moving.

\section{THE STATIONARY SURVEY TECHNIQUE}

The majority of areas were surveyed by the stationary technique. Several fixed survey points were chosen to offer a maximum view of an area and minimize the impact from an observer's presence. A survey time of one hour was allocated to each survey location which allowed the researcher to look in different directions to maximize the amount of data gathered from each point.

\section{THE MOVING SURVEY TECHNIQUE}

Geographic considerations in some habitat areas made the stationary technique very inefficient. For example, some habitat areas occurred in rolling terrain or forested areas. Application of the stationary method to such areas required a large number of survey points, each covering an area too small to justify a full one-hour survey. Thus, a moving survey technique was implemented in these areas. The moving survey method involved slowly moving through an area and stopping for 15 to 30 minutes at points which offered a good view.

\section{MEASUREMENTS}

Four hundred fifty two detailed marmot observations were analyzed for 1994, and 456 for 1995. Data collection occurred in the morning and late afternoon (roughly 7-11am and 3-7pm), since marmot activity was highest during these times.

three categories:

Marmots were classified by pelage type into

1. melanistic pelage -_animals that appeared entirely black except for white or tan patches on the face (Fryxell 1928; Armitage 1961);

2. normal pelage - yellowish-brown animals with yellow bellies, and white between the eyes (Burt \& Grossenheider, 1976);

3. other pelage - any color variation that could not be classified as melanistic or normal, such as hoary, gray, or incomplete black.
Additionally, three age categories were defined: juveniles, subadults, and adults.

Marmot observations were classified according to the following categories: distance from a burrow $(<5 \mathrm{~m},>5 \mathrm{~m})$, accompanied by young, accompanied by others of same size, activity (foraging, sunning, nursing, grooming, watching, nest building, other), and social interaction (communication, play, aggressive, submissive, avoidance, none, other).

\section{$\downarrow \quad$ RESULTS AND DISCUSSION}

All inferences and statistical tests were interpreted at a level of significance of $\mathbf{P}=0.05$.

\section{MELANISM AND HUMAN IMPACT}

Tables 1 and 2 (see Appendix for all tables) summarize data collected during the summers of 1994 and 1995, respectively. The data represent the number of marmots encountered in specific locations according to the three fur colorations. This information was used to estimate the proportion of marmots with each pelage color in all study areas for a specified year.

Table 3 presents average daily backcountryuse information obtained from trail counters for the months of August, 1993, and July and August, 1994/95. The information was used to estimate numbers of people in each backcountry area.

Human impact in the backcountry was measured using: 1) estimated numbers of hikers per day in a location; and 2) by two Experts = Design Analyses, one completed in 1994 and one in 1995. The Experts $=$ Design Analyses were used to quantify human impact by including variables such as (overnight use, off-trail hiking, nature of the hikers, etc.).

Table 4 presents the results of a backcountry-use survey given to 13 experienced backcountry rangers. The survey was based on a 1to-10 Likert scale (1 represented minimal human use; 10, maximum use), designed to measure relative human concentration in backcountry locations using an Experts' Analysis approach. A sample survey sheet is presented in the Appendix. 
Table 5 presents the results of a backcountry-use survey given to 16 experienced backcountry rangers in 1995 . The experiment was based on a Least-Most Discrete Choice Analysis (LMDCA) approach designed to calculate a relative human influence score (RHIS) in backcountry locations also using an Experts' Design Analysis. The analysis strategy is considered to be much more precise than Likert scales in quantifying variables of interest. In general, a higher RHIS for a specified location indicates that more human influence, or impact, is exhibited in that area.

The experiment consisted of 16 scenarios based on a balanced incomplete block design. Each scenario consisted of six geographical regions chosen from a total of sixteen defined regions of interest in GTNP. Each region occurred in six of the 16 scenarios, each pair of regions occurred in two scenarios, and each region occurred one time in each of the six possible positions within a scenario. An expert was asked to pick the region most impacted by humans and the region least impacted by humans for each of the 16 scenarios. A sample survey sheet is provided in the Appendix.

Internal model validity for the LMDCA was examined, and an internal reliability analysis of experts' responses was also performed by repeating four randomly chosen scenarios with the areas arranged in a different sequence. Internal model validity was demonstrated by a McFadden's Rhosquare for model goodness of fit of 0.84 , indicating an excellent fit (Edwards 1994). The reliability analysis was performed by calculating the Kappa coefficient of agreement for the repeated scenarios. For the most human influenced area choice, the Kappa coefficient was $0.753(\underline{P}<0.01)$, indicating a substantial agreement. For the least human influenced area choice, the Kappa coefficient was $0.938(P<0.01)$, indicating near perfect agreement (Landis and Koch 1977). Thus the model proved to be both valid and reliable.

Information from Tables 1 through 5 was compiled in an attempt to correlate geographic variation in the incidence of the melanistic phenotype with the intensity of human use. Table 6 summarizes this information from the perspective of the relative human concentration score (RHCS) and the relative human influence score (RHIS). Table 7 summarizes this information from the perspective of estimated numbers of people using the backcountry in selected regions.
Several correlation coefficients were computed to investigate the relationship between the proportion of melanism and human use of the environment. Table 8 lists Spearman's rank correlation coefficients and p-values resulting from pairwise correlations of the proportion of melanistic marmots in 1994 and 1995 with the RHCS of 1994 and RHIS of 1995 (refer to Table 6). Table 9 lists Pearson's correlation coefficients and p-values resulting from pairwise correlations of the proportion of melanistic marmots in 1994 and 1995 with backcountry use in 1994 and 1995 (refer to Table 7).

The correlation analysis suggests that the presence of humans is not related to the incidence of melanism when all areas of GTNP are included in the analysis. However, the analysis may be inadequately balanced, mainly due to the fact that the vast majority of marmot observations occurred in regions associated with substantial human activity (popular trails, lakes, etc.), and marmots were rarely encountered $300 \mathrm{~m}$ from these areas, or in other isolated areas where minimal time was spent monitoring these animals. In the following section (Spatial Implications), this inconsistency may be resolved by emphasizing only those areas with high human use and negligible human use in the analysis.

Finally, the Spearman's rank correlation coefficient resulting from correlating the RHCS and RHIS was $0.938(\mathbb{P}<0.01)$, suggesting that the Likert scale approach contained nearly all the information provided by the LMDCA. Since the Likert experiment is much easier to implement, answer, and analyze, the LMDCA may not be necessary. Future investigation is merited.

\section{SPATIAL IMPLICATIONS}

Surveys conducted in very remote areas of GTNP during the three previous summers have produced few marmot sightings:

1) surveys of over $160 \mathrm{~km}$ of mountainous terrain west of Jackson Lake to the Continental Divide, over a 9-day period during 3 summers, have never documented a melanistic marmot, and the backcountry rangers that patrol that sparsely-used area of the park have reported only one sighting during the past 3 summers (Montopoli, pers. obs.);

2) in 1994, Avalanche Canyon was surveyed for an entire day and resulted in 2 marmot 
3)

sightings (Visser, pers. obs.); and in 1994, an off-trail hike of approximately $12 \mathrm{~km}$ (from Fox Creek Pass, northeast to Forget-Me-Not Lakes along a large shelf, east to Rimrock Lake, and north to Death Canyon trail) produced only one marmot sighting (Montopoli, pers. obs.).

A hypothesis test was conducted to investigate significant differences in numbers of marmots encountered in negligible and high human use areas defined by the RHIS scale. Two areas of negligible human use (Avalanche and Leigh Canyons) were compared to four randomly selected areas of high human use (Lower Saddle, Garnet Meadows, NF Cascade Canyon, and Surprise/Amphitheater Lakes). The random selection was based on providing an equal amount of time for the high use areas (Table 10).

Of 70 total marmot observations, $70 \%$ occurred in high use areas, while $30 \%$ occurred in negligible use areas. A simple proportion z-test resulted in a value of $3.347(P=0.0008)$, indicating that a proportionately greater number of marmots were observed in areas of high human use.

Finally, the proportion of melanistic marmots in the four high use areas was $10.27 \%$, while the proportion of melanistic marmots in the two negligible use areas was $0.0 \%$. Thus, when only comparing areas at the two extremes of human use, the proportion of melanistic marmots may be indicative of human impact. Future studies will be directed to this investigation.

\section{DIFFERENTIAL SURVIVAL OF MELANISTIC AND NON-MELANISTIC PHENOTYPES}

Differential survival rates of melanistic and non-melanistic phenotypes were examined for 1994 and 1995 by comparing the proportions of marmots corresponding to the different age classes (juveniles, subadults, and adults) for each pelage type (normal, melanistic, and other). The years were analyzed separately because of substantial differences in snow conditions and weather.

Table 11 presents frequencies and proportions of age categories for each pelage type for 1994. A chi-square test of independence was performed to check for significant differences in frequencies among each age category for different fur colorations. The test produced a chi-square value of $28.866(\underline{P}<0.0000)$, indicating that differential survival rates were exhibited among age groups for a given fur coloration. Figure 1 depicts the 1994 proportions.

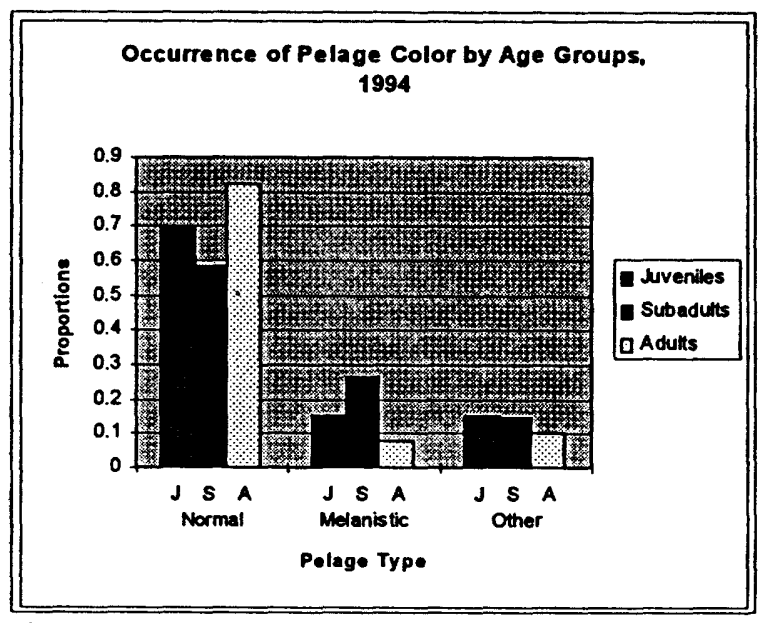

Figure 1. Occurrence of pelage color by age groups, 1994

To examine which age groups within a specified fur coloration differed significantly, nine tests of pairwise differences of proportions were performed. The results are listed in Table 12.

The proportion of adults with normal fur color significantly exceeded both subadults with normal fur coloration $(\underline{P}<0.0000)$, and juveniles with normal fur color $(\underline{P}=0.0098)$. Given melanistic fur coloration, the proportion of subadults was significantly higher than both juveniles $(\underline{P}=0.0416)$ and adults $(P<0.0000)$, while the proportion of juveniles exceeded that of adults $(P=0.0364)$. There were no significant differences among age groups given fur coloration that cannot be categorized as normal or melanistic (the "other" category).

Since several null hypotheses were tested in the same experiment (nine multiple comparisons were performed), a Bonferroni adjustment was implemented to control experimentwise Type I error, while preserving the 0.05 overall level of significance. An experimentwise level of significance of $\alpha_{\mathrm{ew}}=0.05 / 9=0.0056$ was employed (Woodward, Bonett, \& Brecht 1990). Using $\alpha_{\text {ew }}$, the proportion of adults with normal fur color significantly exceeded the proportion of subadults with normal coloration $(P<0.0000)$, and the proportion of melanistic subadults was significantly higher than the proportion of melanistic 
adults $(P<0.0000)$. For both the melanistic and normal fur pelages, significant differences occurred between subadult and adult age groups; however, more normal adults survived, while fewer melanistic adults survived.

The same analysis was performed for the 1995 data. Table 13 presents frequencies and proportions of age categories for each pelage type for 1995. A chi-square test of independence indicated significant differences in frequencies among each age category for different fur colorations. The test produced a chi-square value of $15.220(P=0.0043)$, indicating that differential survival rates were exhibited among age groups for a given fur coloration. Figure 2 depicts the 1995 proportions.

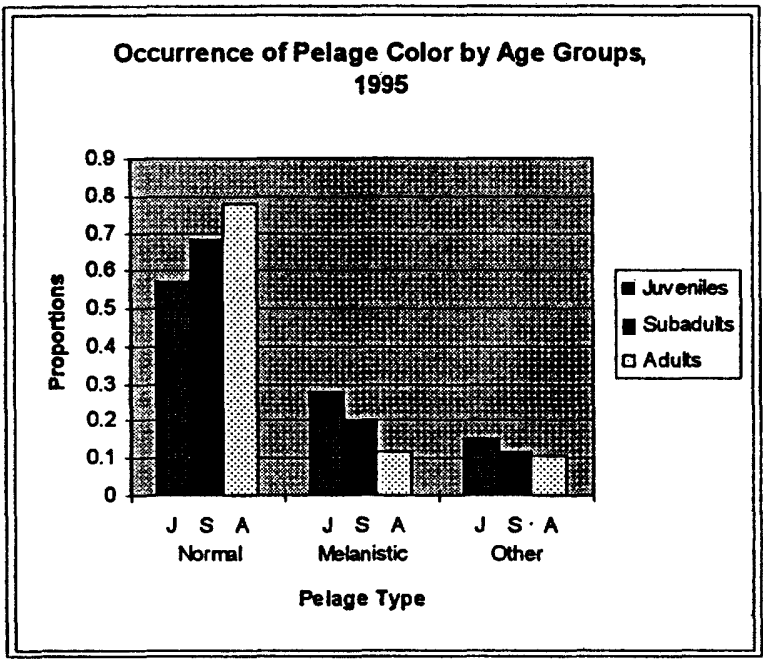

Figure 2. Occurrence of pelage color by age groups, 1995.

From Table 14, the proportion of adults with normal fur color significantly exceeded both subadults with normal fur coloration $(P=0.0405)$, and juveniles with normal fur color $(P=0.0004)$.

Given melanistic fur coloration, the proportion of adults was significantly lower than both juveniles $(P$ $=0.0007)$ and subadults $(P=0.0183)$, while the proportion of juveniles exceeded that of adults $\mathbb{P}=$ 0.0364). There were no significant differences among age groups given fur coloration corresponding to the "other" category.

Using the experimentwise level of significance of 0.0056 , only the proportion of adults with normal fur color significantly exceeded the proportion of juveniles with normal fur coloration $(\underline{P}=0.0004)$, and the proportion of melanistic juveniles was significantly higher than the proportion of melanistic adults $(P=0.0007)$. In both the melanistic and normal fur pelages, significant differences occurred between juvenile and adult age groups, however, more normal adults survived, while fewer melanistic adults survived. The trend was similar to that in 1994, except that in 1995 the significant differences occurred between juveniles and adults instead of subadults and adults (as was the case in 1994).

\section{TEMPORAL IMPLICATIONS}

Climatic conditions, especially snow level at higher altitudes $(>2000 \mathrm{~m})$, differed greatly in 1994 and 1995. While 1994 was characterized as a somewhat dry year, 1995 was characterized by late, heavy snowfalls that left deep snow in areas such as Cascade Canyon well into late July (J. Woodmencey, Jackson Hole meteorologist, pers. comm., 1996). In 1994, snow had dissipated by mid-June. Consequently, high marmot mortality and limited reproduction, with large changes in population dynamics were anticipated. However, as depicted in Fig. 3 the expected "drastic" changes in population dynamics did not occur.

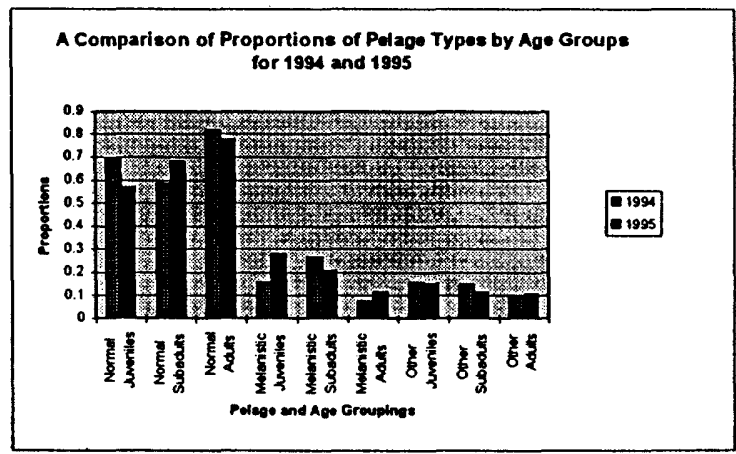

Figure 3. A comparison of proportions of pelage types by age groups for 1994 and 1995.

A chi-square test of homogeneity was performed to examine if the pelage and age groupings across the two years were significantly different. The test resulted in a chi-square value of $17.377(\underline{P}=0.0264)$, indicating a small but significant, difference. However, this difference would not be classified as biologically relevant. Finally, caution must be exercised in interpreting this result since the marmot counts for the two years were not independent; that is, some marmots counted in 1994 probably were counted in 1995.

In 1959, Armitage found that about $23.42 \%(n=111)$ of the marmots he surveyed were 
melanistic, which differs significantly $(\underline{\mathrm{P}}<0.000)$ from the proportion of melanistic individuals for all surveyed populations in GTNP in $1994(15.49 \%, \mathrm{n}$ $=452)$, and in $1995(16.67 \%, \mathrm{n}=456)$. Populations certainly experience temporal fluctuations, but these changes may occur slowly over time, even in the presence of large climatic changes.

\section{ACKNOWLEDGMENTS}

This research was made possible through funding from the University of Wyoming Faculty Grant-in-Aid Program and the University of Wyoming-National Park Service Unsolicited Grant Program. We extend our deepest gratitude to these respective agencies.

In addition, for assistance with all aspects of this project, we wish to express our sincere gratitude to Kim Springer, Don Roth, Adrianna Valladares, Michael Crone, Steve Bieber, Richard Anderson-Sprecher, Doug Bonett, Myron Allen, and other University of Wyoming personnel, for their support and technical expertise; to Alan Harmata, for technical expertise; to Steve Cain, Rick Wallen, Mason Reed, Dan Burgette, the Jenny Lake Rescue Rangers, and other Grand Teton National Park personnel, for their participation and collaboration; to Ken Armitage and Dan Blumstein, University of Kansas, for their advice and technical expertise; to the Jackson Hole Ski Corporation, especially Corky Ward and Bruce Adams, for cooperation with transportation and other assistance; to the Jenny Lake Teton Boating Enterprise, especially Brent Miller, for cooperation with transportation across Jenny Lake and friendly encouragement; to Laura Archer, Oliver Deshler, Zach Harlow, Siri Ibarguan, Hal Janson, Helen Larson, Heather McDonald, Sean Mohren, and Mark Stichert, for volunteering their time in the field; to Delia Montopoli, and Michelle Montopoli, for support and assistance in trapping and observing marmots.

\section{LITERATURE CITED}

Armitage, K. B. 1961. Frequency of melanism in the golden-mantled marmot. J. Mammal. 42:100-101.
, 1982. Marmots and coyotes: Behavior of prey and predator. J. Mamm. 63(3):503505.

Burt, W.H. and Grossenheider, R.P. 1976. A field guide to the mammals of America north of Mexico (3rd ed.). Houghton Mifflin Company, Boston.

Craighead, F. C. Jr. 1951. A biological and economic evaluation of coyote predation. New York Zool. Soc. 23 pp.

Edwards, D. 1994. An empirical comparison of maximum difference sensitivity modeling and discrete choice analysis. Ph.D. Thesis, University of Wyoming, Laramie.

Fryxell, F. M. 1928. Melanism among the marmots of the Teton Range, Wyoming. J. Mammal. 9:336-337.

Kilgore, D. L. Jr. 1972. Energy dynamics of the yellow-bellied marmot (Marmota flaviventris): A hibernator. Ph.D. Thesis, The University of Kansas, Lawrence. 82pp.

Kiltie, R. A. 1989. Wildfire and the evolution of dorsal melanism in fox squirrels, (Sciurus niger). J. Mammal. 70(4):726-739.

Landis, R. and Koch, G. 1977. The measurement of observer agreement for categorical data. Biometrics. 33:159-174.

Murie, O. J. 1934. Melanism in an Alaskan vole. J. Mammal. 15:323.

Swarth, H.S. 1912. Univ. of California Publ. Zool., X, 89-90.

Travis, S. E. and Armitage, K. E. 1972. Some quantitative aspects of the behavior of marmots. Trans. Kan. Acad. Sci. 75(4):308-321.

Walsberg, G. E., Campbell, G. S., and King, J. R. 1978. Animal coat color and radiative heat gain: A re-evaluation. Jour. Comp. Physiol. 126:211-222. 
Woodward, J.A., Bonett, D.G., and Brecht, M. 1990. Introduction to linear models and experimental design. Harcourt Brace Jovanovich Publishers, Academic Press, Austin. 


\section{LIST OF FIGURES AND TABLES}

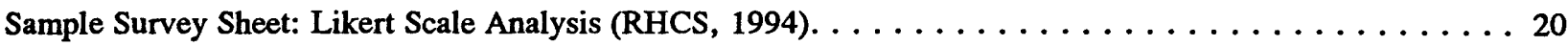

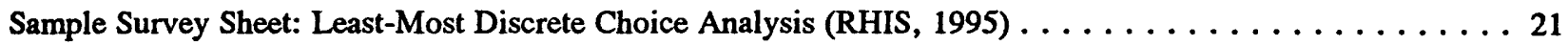

Table 1. Incidence of Pelage Color by Survey Areas, $1994 \ldots \ldots \ldots \ldots \ldots \ldots \ldots \ldots \ldots \ldots \ldots$

Table 2. Incidence of Pelage Color by Survey Areas, $1995 \ldots \ldots \ldots \ldots \ldots \ldots \ldots \ldots \ldots \ldots$

Table 3. Backcountry Use Information from Trail Counters $\ldots \ldots \ldots \ldots \ldots \ldots \ldots \ldots \ldots \ldots \ldots$

Table 4. Relative Human Concentration Score, $1994 \ldots \ldots \ldots \ldots \ldots \ldots \ldots \ldots \ldots \ldots \ldots \ldots \ldots$

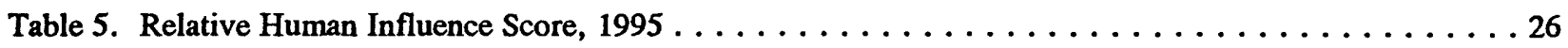

Table 6. Proportion of Melanistic Marmots Versus

Human Concentration and Influence Scores . . . . . . . . . . . . . . . 27

Table 7. Proportion of Melanistic Marmots Versus

Backcountry Use . . . . . . . . . . . . . . . . . . . . 28

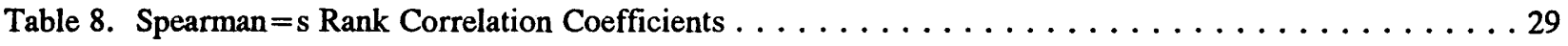

Table 9. Pearson $=$ s Correlation Coefficients . . . . . . . . . . . . . . . . . . . 29

Table 10. Frequencies of Marmots in Low and High Use Areas . . . . . . . . . . . . . . . . . 29

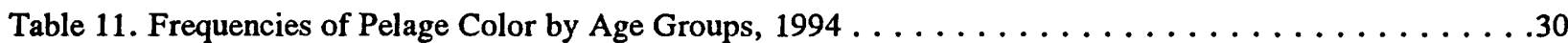

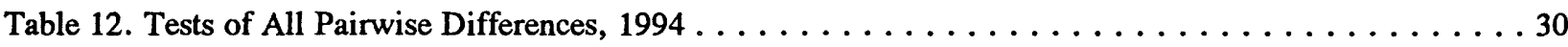

Table 13. Frequencies of Pelage Color by Age Groups, $1995 \ldots \ldots \ldots \ldots \ldots \ldots \ldots \ldots \ldots \ldots$

Table 14. Tests of All Pairwise Differences, $1995 \ldots \ldots \ldots \ldots \ldots \ldots \ldots \ldots \ldots \ldots \ldots \ldots \ldots$

Table 15. Frequencies of Marmots Previous to Snow Melt

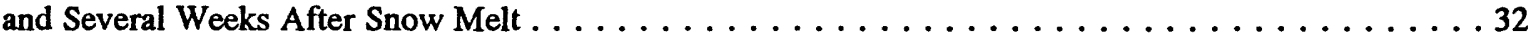


Figure 1. Likert Scale Analysis (RHCS, 1994)

For the locations listed below, please indicate your best estimate of human use (or concentration of humans) throughout the zone, based on a 10-scale, with 1 representing MINIMAL use and 10 representing MAXIMUM use.

Min $\quad$ Max

Cascade Cyn (W. Dock to Insp Point).. . . . . . . . . . . . .

Cascade Cyn (Insp.Point to Forks)... . . . . . . . . . . . .

Cascade Cyn (Forks to Sol. Lake)..

Cascade Cyn (Forks to Hurr. Pass)

Hanging Canyon.

Lower Paintbrush Cyn .

Holly Lake Area.

Upper Paintbrush To Paint. Divide

Grizzly Bear Lake

Surprise/Amphitheater Lakes

Garnet Cyn (Platforms/Meadows).

Garnet Cyn (Caves/Moraine).

Garnet Cyn (Lower Saddle).

Garnet Cyn (South Fork).

Avalanche Canyon .

Death Cyn (Phelps Lk to Fox Ck Pass).

Death Shelf

Granite Cyn (South/Middle Forks).

Granite Cyn (P.A. to below-Marion Lk).

Marion Lake Area

String Lake to Trapper Lake

Leigh Lake to CMC Campsite Moran). 
Figure 2. Least Most Discrete Choice Set Analysis (RHIS, 1995)

The following locations in GTNP will be presented to you for evaluation in 20 scenarios, with any 6 locations occurring in each scenario:

1. Cascade Canyon: Inspiration Point to Forks

2. Cascade Canyon: Forks to Solitude Lake

3. Cascade Canyon: Forks to Hurricane Pass

4. Death Canyon: Phelps Lake to Fox Creek Pass

5. Death Canyon: Death Shelf

6. Avalanche Canyon: Taggart Lake to Snowdrift Lake

7. Garnet Canyon: Platforms/Meadows/Caves

8. Garnet Canyon: Lower Saddle Area

9. Garnet Canyon: South Fork

10. Hanging Canyon: Jenny Lake to Lake of the Crags

11. Marion Lake Area

12. Paintbrush Canyon: Group Site to below Holly Lake

13. Paintbrush Canyon: Holly Lake Area

14. Paintbrush Canyon: above Holly Lake to Paintbrush Divide

15. Surprise/Amphitheater Lake Area

16. Leigh Canyon: Leigh Lake to Mink Lake

For each scenario, please indicate which area is most impacted by humans and which area is least impacted by humans, based on your experience.

\begin{tabular}{|l|l||}
\hline \hline- & $\frac{\text { most }}{\text { Least }}$ \\
- & $\frac{\text { Paigh Canyon: Leigh Lake to Mink Lake }}{\text { Gaintbrush Canyon: Group Site to below Holly Lake }}$ \\
- & $\frac{\text { Death Canyon: Phelps Lake to Fox Creek Pass }}{\text { Death Canyon: Death Shelf }}$ \\
\hline
\end{tabular}

\begin{tabular}{|l|l|}
\hline- & $\frac{\text { Paintbrush Canyon: Holly Lake Area }}{\text { Paintbrush Canyon: Group Site to below Holly Lake }}$ \\
- & $\frac{\text { Paintbrush Canyon: above Holly Lake to Paintbrush Divide }}{\text { Cascade Canyon: Inspiration Point to Forks }}$ \\
\hline- & $\frac{\text { Leigh Canyon: Leigh Lake to Mink Lake }}{\text { Garnet Canyon: South Fork }}$ \\
\hline
\end{tabular}


Table 1. Incidence of Pelage Color by Survey Areas, 1994

\begin{tabular}{|c|c|c|c|}
\hline $\begin{array}{c}\text { Location } \\
(\mathrm{n}=\text { number of surveys) }\end{array}$ & $\begin{array}{l}\text { Number of } \\
\text { Melanistic }\end{array}$ & $\begin{array}{l}\text { Number } \\
\text { of Normal }\end{array}$ & $\begin{array}{l}\text { Number of } \\
\text { Other }\end{array}$ \\
\hline Alaska Basin $(n=2)$ & 4 & 11 & 1 \\
\hline Avalanche Canyon $(n=1)$ & 0 & 2 & 0 \\
\hline $\begin{array}{l}\text { Cascade Canyon: } \\
\text { Jenny Lake to Forks }(n=5) \\
\text { Forks to Solitude Lake }(n=6) \\
\text { Solitude Lake Area }(n=4) \\
\text { Forks to Hurricane Pass }(n=4)\end{array}$ & $\begin{array}{l}2 \\
6 \\
4 \\
1\end{array}$ & $\begin{array}{l}12 \\
63 \\
10 \\
23 \\
\end{array}$ & $\begin{array}{l}0 \\
6 \\
2 \\
4\end{array}$ \\
\hline $\begin{array}{c}\text { Death Canyon: } \\
\text { Phelps Lake to Cabin }(n=2) \\
\text { Cabin to Fox Creek Pass }(n=1) \\
\text { Death Shelf }(n=4)\end{array}$ & $\begin{array}{l}3 \\
1 \\
0\end{array}$ & $\begin{array}{c}8 \\
2 \\
23 \\
\end{array}$ & $\begin{array}{l}0 \\
0 \\
5\end{array}$ \\
\hline $\begin{array}{c}\text { Garnet Canyon: } \\
\text { Trail to Platforms }(n=5) \\
\text { Meadows Area }(n=1) \\
\text { Lower Saddle Area }(n=4) \\
\text { South Fork Area }(n=3) \\
\text { Above Lower Saddle/Grand }(n=1)\end{array}$ & $\begin{array}{l}6 \\
0 \\
2 \\
0 \\
2\end{array}$ & $\begin{array}{c}7 \\
6 \\
33 \\
9 \\
0\end{array}$ & $\begin{array}{l}0 \\
2 \\
3 \\
5 \\
0\end{array}$ \\
\hline $\begin{array}{l}\text { Granite Canyon: } \\
\text { Tram through S/M Forks }(n=1)\end{array}$ & 0 & 3 & 0 \\
\hline $\begin{array}{c}\text { Hanging Canyon: } \\
\text { Trail to Arrowhead Lake }(n=4) \\
\text { Arrowhead to Lake Crags }(n=3) \\
\text { Laurel Lake }(n=1)\end{array}$ & $\begin{array}{l}5 \\
2 \\
0\end{array}$ & $\begin{array}{c}12 \\
7 \\
1\end{array}$ & $\begin{array}{l}0 \\
5 \\
0\end{array}$ \\
\hline $\begin{array}{c}\text { Housing Areas: } \\
\text { Beaver Creek Boneyard }(n=2) \\
\text { Climber's Ranch }(n=3) \\
\text { Highland's Housing Area }(n=2) \\
\end{array}$ & $\begin{array}{l}1 \\
2 \\
6\end{array}$ & $\begin{array}{l}4 \\
6 \\
6\end{array}$ & $\begin{array}{l}0 \\
0 \\
0 \\
\end{array}$ \\
\hline $\begin{array}{c}\text { Isolated Lake Areas: } \\
\text { Delta Lake }(n=1) \\
\text { Grizzly Bear Lake }(n=1) \\
\text { Marion Lake }(n=4) \\
\text { Moose Ponds }(n=1) \\
\text { Surprise/Amphitheater }(n=4)\end{array}$ & $\begin{array}{c}1 \\
0 \\
13 \\
0 \\
1\end{array}$ & $\begin{array}{c}1 \\
2 \\
12 \\
3 \\
7 \\
\end{array}$ & $\begin{array}{l}0 \\
1 \\
2 \\
0 \\
5\end{array}$ \\
\hline $\begin{array}{c}\text { Paintbrush Canyon: } \\
\text { Trail to Holly Lake }(n=2) \\
\text { Holly Lake Area }(n=3) \\
\text { Holly Lake to Divide }(n=5) \\
\end{array}$ & $\begin{array}{l}0 \\
3 \\
4 \\
\end{array}$ & $\begin{array}{l}10 \\
14 \\
12 \\
\end{array}$ & $\begin{array}{c}1 \\
6 \\
10 \\
\end{array}$ \\
\hline $\begin{array}{l}\text { Taggart Lake Burn Area: } \\
\text { Corral to Taggart Lake }(n=5)\end{array}$ & 1 & 15 & 0 \\
\hline
\end{tabular}


Table 2. Incidence of Pelage Color by Survey Areas, 1995

\begin{tabular}{|c|c|c|c|}
\hline $\begin{array}{c}\text { Location } \\
(\mathrm{n}=\text { number of surveys) }\end{array}$ & $\begin{array}{l}\text { Number of } \\
\text { Melanistic }\end{array}$ & $\begin{array}{l}\text { Number } \\
\text { of Normal }\end{array}$ & $\begin{array}{l}\text { Number of } \\
\text { Other }\end{array}$ \\
\hline Avalanche Canyon $(n=1)$ & 0 & 0 & 0 \\
\hline $\begin{array}{c}\text { Cascade Canyon: } \\
\text { Jenny Lake to Forks }(n=8) \\
\text { Forks to Solitude Lake }(n=3) \\
\text { Solitude Lake Area }(n=2) \\
\text { Forks to Hurricane Pass }(n=3) \\
\end{array}$ & $\begin{array}{l}1 \\
8 \\
3 \\
4\end{array}$ & $\begin{array}{c}5 \\
30 \\
6 \\
32 \\
\end{array}$ & $\begin{array}{l}0 \\
3 \\
0 \\
5\end{array}$ \\
\hline $\begin{array}{l}\text { Death Canyon: } \\
\text { Phelps Lake to Cabin }(n=1) \\
\text { Cabin to Fox Creek Pass }(n=0) \\
\text { Death Shelf }(n=2)\end{array}$ & $\begin{array}{l}6 \\
1 \\
0\end{array}$ & $\begin{array}{c}15 \\
0 \\
17\end{array}$ & $\begin{array}{l}1 \\
0 \\
3\end{array}$ \\
\hline $\begin{array}{l}\text { Garnet Canyon: } \\
\text { Trail to Platforms }(n=7) \text { Meadows Area }(n=2) \\
\text { Lower Saddle Area }(n=2)\end{array}$ & $\begin{array}{l}1 \\
1 \\
2\end{array}$ & $\begin{array}{c}19 \\
6 \\
7\end{array}$ & $\begin{array}{l}7 \\
2 \\
3\end{array}$ \\
\hline $\begin{array}{c}\text { Granite Canyon: } \\
\text { Cody Peak Area }(n=1) \\
\text { Rendezvous Peak Area }(n=1) \\
\text { Tram through S/M Forks }(n=2)\end{array}$ & $\begin{array}{l}1 \\
0 \\
4\end{array}$ & $\begin{array}{l}1 \\
2 \\
6\end{array}$ & $\begin{array}{l}0 \\
0 \\
0\end{array}$ \\
\hline $\begin{array}{l}\text { Hanging Canyon: } \\
\text { Trail to Arrowhead Lake }(n=2) \\
\text { Arrowhead to Lake Crags }(n=2) \\
\text { Laurel Lake }(n=1)\end{array}$ & $\begin{array}{l}3 \\
0 \\
1\end{array}$ & $\begin{array}{c}22 \\
7 \\
6\end{array}$ & $\begin{array}{l}2 \\
1 \\
1\end{array}$ \\
\hline $\begin{array}{c}\text { Housing Areas: } \\
\text { Beaver Creek Boneyard }(n=6) \\
\text { Climber's Ranch }(n=1) \\
\text { Highland's Housing Area }(n=2) \\
\text { Lupine Meadow's Area }(n=5) \\
\text { Rudd's Corral Area }(n=2) \\
\end{array}$ & $\begin{array}{c}9 \\
0 \\
3 \\
15 \\
0 \\
\end{array}$ & $\begin{array}{c}12 \\
7 \\
16 \\
10 \\
4\end{array}$ & $\begin{array}{l}0 \\
1 \\
3 \\
2 \\
3\end{array}$ \\
\hline $\begin{array}{c}\text { Isolated Lake Areas: } \\
\text { Marion Lake }(n=2) \\
\text { Surprise/Amphitheater }(n=3)\end{array}$ & $\begin{array}{l}4 \\
1\end{array}$ & $\begin{array}{c}13 \\
8 \\
\end{array}$ & $\begin{array}{l}1 \\
0\end{array}$ \\
\hline Leigh Canyon to Lower $\operatorname{Lk}(\mathrm{n}=2)$ & 0 & 19 & 3 \\
\hline $\begin{array}{c}\text { Paintbrush Canyon: } \\
\text { Trail to Holly Lake }(n=4) \\
\text { Holly Lake Area }(n=3) \\
\text { Holly Lake to Divide }(n=2) \\
\end{array}$ & $\begin{array}{l}1 \\
2 \\
3\end{array}$ & $\begin{array}{c}5 \\
3 \\
19 \\
\end{array}$ & $\begin{array}{l}5 \\
2 \\
4\end{array}$ \\
\hline $\begin{array}{c}\text { Taggart Lake Burn Area: } \\
\text { Corral to Taggart Lake }(n=5)\end{array}$ & 1 & 26 & 1 \\
\hline Teewinot Apex Trail $(n=2)$ & 1 & 4 & 0 \\
\hline
\end{tabular}


Table 3. Backcountry Use Information from Trail Counters

\begin{tabular}{|l|c|}
\hline \multicolumn{1}{|c|}{ Location } & \multicolumn{1}{|c|}{$\begin{array}{c}\text { Average Number of People } \\
\text { per Day (June - August) }\end{array}$} \\
\hline Avalanche Canyon & $6.1^{1}$ \\
\hline Cascade Canyon: & $946.9^{2}$ \\
Boat Traffic & 402.7 \\
Jenny Lake, SW Shore & 236.2 \\
String Lake, South & 179.9 \\
\hline Death Canyon & \\
\hline Garnet Canyon: & 171.0 \\
Lupine Meadows Trailhead & 97.2 \\
Surprise Lake Cutoff & 71.5 \\
\hline Garnet Canyon Cutoff & \\
\hline Granite Canyon: & 24.5 \\
Tram & 76.6 \\
\hline Granite Parking Area & $19.1^{3}$ \\
\hline Hanging Canyon & 164.1 \\
\hline Taggart Lake Trail & 263.2 \\
\hline String Lake, North & \\
\hline
\end{tabular}

${ }^{1}$ Estimated from 1993 data only (1994/95 data not available)

${ }^{2}$ Estimated from 1993/95 data only (1994 data not available)

${ }^{3}$ Estimated from 1994/95 data only (1993 data not available)

Note: All other values are estimated from 1993/94/95 data. 
Table 4. Relative Human Concentration Score, 1994

\begin{tabular}{|l|c|}
\hline \multicolumn{1}{|c|}{ Location } & Average Score \\
\hline Avalanche Canyon & 2.54 \\
\hline Cascade Canyon: & \\
Jenny Lake to Inspiration Point & 10.00 \\
Inspiration Point to Forks & 8.23 \\
Forks to Solitude Lake & 6.85 \\
Forks to Hurricane Pass & 5.46 \\
\hline Death Canyon: & \\
Phelps Lake to Fox Creek Pass & 5.46 \\
Death Shelf & 4.54 \\
\hline Garnet Canyon: & \\
Platforms/Meadows & 7.77 \\
Pedzoldt's Caves & 7.46 \\
Lower Saddle & 7.58 \\
South Fork & 5.62 \\
\hline Granite Canyon: & \\
North Fork & 4.77 \\
South/Middle Forks & 4.54 \\
\hline Hanging Canyon & 4.00 \\
\hline Backcountry Lakes: & \\
Grizzly Bear Lake & 1.92 \\
Marion Lake & 5.62 \\
Surprise/Amphitheater Lakes & 7.46 \\
\hline Paintbrush Canyon: & \\
Lower Paintbrush & 5.77 \\
Holly Lake & 5.85 \\
Upper Paintbrush & 4.54 \\
\hline String/Leigh Lake Area: & \\
String Lake to Trapper Lake & 2.67 \\
Leigh Lake to CMC Camp (Moran) & \\
\hline & \\
\hline
\end{tabular}


Table 5. Relative Human Influence Score, 1995

\begin{tabular}{|l|c|c|}
\hline \multicolumn{1}{|c|}{ Location } & RHIS & SE RHIS \\
\hline Avalanche Canyon & 1.34576 & 0.38694 \\
\hline Cascade Canyon: & & \\
Inspiration Point to Forks & 8.81705 & 0.61132 \\
Forks to Solitude Lake & 8.53804 & 0.61603 \\
Forks to Hurricane Pass & 5.16900 & 0.57549 \\
\hline Death Canyon: & & \\
Lower and Upper Canyon & 5.94026 & 0.61503 \\
Death Shelf & 4.13493 & 0.51695 \\
\hline Garnet Canyon: & & \\
Platforms/Meadows/Caves & 9.76789 & 0.61037 \\
Lower Saddle & 10.07063 & 0.61506 \\
South Fork & 4.36597 & 0.52768 \\
\hline Hanging Canyon & 3.33158 & 0.49061 \\
\hline Backcountry Lakes: & & \\
Marion Lake & 7.57249 & 0.60221 \\
Surprise/Amphitheater Lakes & 9.11947 & 0.61403 \\
\hline Paintbrush Canyon: & & \\
Lower Paintbrush & 6.36287 & 0.66861 \\
Holly Lake & 8.18085 & 0.62706 \\
Upper Paintbrush & 4.48777 & 0.00000 \\
\hline Leigh Canyon & & \\
\hline
\end{tabular}

ne $=$ not estimable 
Table 6. Proportion of Melanistic Marmots Versus Human Concentration and Influence Scores

\begin{tabular}{|c|c|c|c|c|}
\hline Location & $\begin{array}{l}\text { Prop. } \\
\text { Melanistic } \\
\text { Marmots } \\
(1994)\end{array}$ & $\begin{array}{l}\text { Prop. Melanistic } \\
\text { Marmots } \\
\text { (1995) }\end{array}$ & $\begin{array}{l}\text { Human } \\
\text { Conc. } \\
\text { Score } \\
(1994)\end{array}$ & $\begin{array}{l}\text { Human } \\
\text { Infl. } \\
\text { Score } \\
(1995)\end{array}$ \\
\hline Avalanche Canyon: & $0.000(2)$ & $0.000(0)$ & 2.54 & 1.35 \\
\hline $\begin{array}{l}\text { Cascade Canyon: } \\
\text { Jenny Lk. to Forks } \\
\text { Forks to Solitude Lk } \\
\text { Forks to Hurricane }\end{array}$ & $\begin{array}{l}0.143(14) \\
0.110(91) \\
0.036(28)\end{array}$ & $\begin{array}{l}0.167(6) \\
0.220(50) \\
0.098(41)\end{array}$ & $\begin{array}{l}9.12 \\
6.85 \\
5.46\end{array}$ & $\begin{array}{l}8.82 \\
8.54 \\
5.16\end{array}$ \\
\hline $\begin{array}{l}\text { Death Canyon: } \\
\text { Lower/Upper Canyon } \\
\text { Death Shelf }\end{array}$ & $\begin{array}{l}0.286(14) \\
0.000(23)\end{array}$ & $\begin{array}{l}0.304(23) \\
0.000(20)\end{array}$ & $\begin{array}{l}5.46 \\
4.54\end{array}$ & $\begin{array}{l}5.94 \\
4.13\end{array}$ \\
\hline $\begin{array}{l}\text { Garnet Canyon: } \\
\text { Platforms --> Caves } \\
\text { Lower Saddle } \\
\text { South Fork }\end{array}$ & $\begin{array}{l}0.000(8) \\
0.053(38) \\
0.000(14)\end{array}$ & $\begin{array}{c}0.111(9) \\
0.167(12) \\
*\end{array}$ & $\begin{array}{l}7.62 \\
7.58 \\
5.62\end{array}$ & $\begin{array}{r}9.77 \\
10.07 \\
4.37\end{array}$ \\
\hline Granite Canyon: & $0.000(3)$ & $0.400(10)$ & 4.66 & * \\
\hline Hanging Canyon: & $0.226(31)$ & $0.086(35)$ & 4.0 & 3.33 \\
\hline $\begin{array}{l}\text { Isolated Lakes: } \\
\text { Grizzly Bear Lake } \\
\text { Marion Lake } \\
\text { Surprise/Amph. Lk }\end{array}$ & $\begin{array}{c}0.000(3) \\
0.481(27) \\
0.077(13)\end{array}$ & $\begin{array}{c}* \\
0.222(18) \\
0.111(9)\end{array}$ & $\begin{array}{l}1.92 \\
5.62 \\
7.46\end{array}$ & $\begin{array}{c}* \\
7.57 \\
9.12\end{array}$ \\
\hline Leigh Canyon & $*$ & $0.000(22)$ & & 0.00 \\
\hline $\begin{array}{c}\text { Paintbrush Canyon: } \\
\text { Lower Paintbrush } \\
\text { Holly Lake } \\
\text { Upper Paintbrush }\end{array}$ & $\begin{array}{l}0.000(11) \\
0.130(23) \\
0.154(26)\end{array}$ & $\begin{array}{l}0.091(11) \\
0.286(7) \\
0.115(26)\end{array}$ & $\begin{array}{l}5.77 \\
5.85 \\
4.54\end{array}$ & $\begin{array}{l}6.36 \\
8.18 \\
4.49\end{array}$ \\
\hline
\end{tabular}

* = missing data

() represents total number of marmots observed in each classification 
Table 7. Proportion of Melanistic Marmots Versus Human Backcountry Use, 1995

\begin{tabular}{|c|l|l|l|l|}
\hline Location & $\begin{array}{l}\text { Propor. } \\
\text { Melanistic } \\
\text { Marmots } \\
(1994)\end{array}$ & $\begin{array}{l}\text { Propor. } \\
\text { Melanistic } \\
\text { Marmots } \\
(1995)\end{array}$ & $\begin{array}{l}\text { Average } \\
\text { Number } \\
\text { People } \\
\text { per Day } \\
(1994)\end{array}$ & $\begin{array}{l}\text { Average } \\
\text { Number } \\
\text { People } \\
\text { per Day } \\
(1995)\end{array}$ \\
\hline Avalanche Canyon: & $0.000(2)$ & $0.000(0)$ & $6.1^{1}$ & $6.1^{1}$ \\
\hline $\begin{array}{c}\text { Cascade Canyon: } \\
\text { Jenny Lk. to Forks } \\
\text { Forks to Sol. Lk. }\end{array}$ & $\begin{array}{l}0.143(14) \\
0.110(91)\end{array}$ & $\begin{array}{l}0.167(6) \\
0.220(50)\end{array}$ & $\begin{array}{l}170.8^{2} \\
96.4^{2}\end{array}$ & $\begin{array}{l}178.6^{2} \\
100.8^{2}\end{array}$ \\
\hline Death Canyon: & $0.108(37)$ & $0.163(43)$ & 175.9 & 179.9 \\
\hline $\begin{array}{c}\text { Garnet Canyon: } \\
\text { Platforms -- > Saddle }\end{array}$ & $0.043(46)$ & $0.143(21)$ & 61.6 & 71.5 \\
\hline Granite Canyon: & $0.000(3)$ & $0.400(10)$ & 101.5 & 101.1 \\
\hline Hanging Canyon: & $0.226(31)$ & $0.086(35)$ & 18.7 & 19.1 \\
\hline Surprise/Amph. Lakes & $0.077(13)$ & $0.111(9)$ & 110.7 & 97.2 \\
\hline Taggart Lake Burn Area & $0.063(16)$ & $0.036(28)$ & 170.8 & 164.1 \\
\hline
\end{tabular}

\footnotetext{
${ }^{1}$ Estimated from 1993 data only (1994/95 data not available)

${ }^{2}$ Values for Number of People per Day are estimated from information provided by GTNP Ranger D. Burgette (pers. comments, 1995), in a study of backcountry trends.
}

() represents total number of marmots observed in each classification 
Table 8. Spearman $=s$ Rank Correlation Coefficients for Pairwise Comparisons of Proportions of Melanistic Marmots in 1994 and 1995 with RHCS and RHIS from Table 6

\begin{tabular}{|c|c|c|c|}
\hline Proportion Melanistic & Score & Correlation Coefficient & P value \\
\hline 1994 & RHCS (1994) & 0.141 & $>0.1$ \\
\hline 1994 & RHIS (1995) & 0.116 & $>0.1$ \\
\hline 1995 & RHCS (1994) & 0.348 & $>0.1$ \\
\hline 1995 & RHIS (1995) & 0.628 & $>0.1$ \\
\hline
\end{tabular}

Table 9. Pearson $=\mathbf{s}$ Correlation Coefficients for Pairwise Comparisons of Proportions of Melanistic Marmots in 1994 and 1995 with Backcountry Use in 1994 and 1995, from Table 7

\begin{tabular}{|c|c|c|c|}
\hline Proportion Melanistic & $\begin{array}{c}\text { Backcountry } \\
\text { Use }\end{array}$ & Correlation Coefficient & P value \\
\hline 1994 & 1994 & 0.058 & 0.8823 \\
\hline 1994 & 1995 & 0.073 & 0.8521 \\
\hline 1995 & 1994 & 0.224 & 0.5622 \\
\hline 1995 & 1995 & 0.251 & 0.5146 \\
\hline
\end{tabular}

Table 10. Frequencies of Marmots in Areas of Negligible and High Human Use (Ten Hours of Observation Time in Each Area)

\begin{tabular}{|c|c|c|c|c|c|}
\hline Human Use & Specific Area & Nor. & Mel. & Oth. & Total \\
\hline \multirow{2}{*}{ Negligible Use } & Avalanche Canyon & 0 & 0 & 0 & \multirow{2}{*}{21} \\
\hline & Leigh Canyon & 19 & 0 & 2 & \\
\hline \multirow{5}{*}{ High Use } & Lower Saddle & 3 & 1 & 3 & \multirow{5}{*}{4} \\
\hline & - & & & & \\
\hline & Garnet Meadows & 4 & 1 & 1 & \\
\hline & NF Cascade Canyon & 28 & 2 & 3 & \\
\hline & Surprise/Amphi. Lks & 2 & 1 & 0 & \\
\hline
\end{tabular}


Table 11. Frequencies of Pelage Color by Age Groups, 1994

\begin{tabular}{|c|c|c|c|c|}
\hline Pelage Type & Juveniles & Subadults & Adults & Total \\
\hline Normal & $\begin{array}{c}67 \\
(0.691)\end{array}$ & $\begin{array}{c}86 \\
(0.585)\end{array}$ & $\begin{array}{c}171 \\
(0.822)\end{array}$ & 324 \\
\hline Melanistic & $\begin{array}{c}15 \\
(0.155)\end{array}$ & $\begin{array}{c}39 \\
(0.265)\end{array}$ & $\begin{array}{c}16 \\
(0.077)\end{array}$ & 70 \\
\hline Other & 15 & $\begin{array}{c}22 \\
(0.101)\end{array}$ & 58 \\
\hline Total & $(0.155)$ & $(0.150)$ & 208 & 452 \\
\hline
\end{tabular}

( ) represents column proportion for frequency in each cell

Table 12. Tests of All Pairwise Differences of Proportions, 1994

\begin{tabular}{|c|c|c|c|}
\hline Fur Coloration & $\begin{array}{c}\text { Compared } \\
\text { Age Categories }\end{array}$ & Z-value & $P$-value \\
\hline \multirow{3}{*}{ Normal } & $\begin{array}{l}\text { Juvenile with } \\
\text { Subadult }\end{array}$ & 1.67 & 0.0950 \\
\hline & $\begin{array}{c}\text { Subadult } \\
\text { with Adult }\end{array}$ & -4.92 & 0.0000 \\
\hline & $\begin{array}{l}\text { Juvenile with } \\
\text { Adult }\end{array}$ & -2.58 & 0.0098 \\
\hline \multirow{3}{*}{ Melanistic } & $\begin{array}{l}\text { Juvenile with } \\
\text { Subadult }\end{array}$ & -2.04 & 0.0416 \\
\hline & $\begin{array}{c}\text { Subadult } \\
\text { with Adult }\end{array}$ & 4.83 & 0.0000 \\
\hline & $\begin{array}{l}\text { Juvenile with } \\
\text { Adult }\end{array}$ & 2.10 & 0.0364 \\
\hline \multirow{3}{*}{ Other } & $\begin{array}{l}\text { Juvenile with } \\
\text { Subadult }\end{array}$ & 0.11 & 0.9156 \\
\hline & $\begin{array}{c}\text { Subadult } \\
\text { with Adult }\end{array}$ & 1.39 & 0.1646 \\
\hline & $\begin{array}{l}\text { Juvenile with } \\
\text { Adult }\end{array}$ & 1.35 & 0.1770 \\
\hline
\end{tabular}


Table 13. Frequencies of Pelage Color by Age Groups, 1995

\begin{tabular}{|c|c|c|c|c|}
\hline Pelage Type & Juveniles & Subadults & Adults & Total \\
\hline Normal & $\begin{array}{c}41 \\
(0.569)\end{array}$ & $\begin{array}{c}90 \\
(0.682)\end{array}$ & $\begin{array}{c}196 \\
(0.778)\end{array}$ & 327 \\
\hline Melanistic & $\begin{array}{c}20 \\
(0.278)\end{array}$ & $\begin{array}{c}27 \\
(0.204)\end{array}$ & $\begin{array}{c}29 \\
(0.115)\end{array}$ & 76 \\
\hline Other & 11 & $\begin{array}{c}27 \\
(0.107)\end{array}$ & 53 \\
\hline Total & $(0.153)$ & $(0.114)$ & 252 & 456 \\
\hline
\end{tabular}

() represents column proportion for frequency in each cell

Table 14. Tests of All Pairwise Differences of Proportions, 1995

\begin{tabular}{|c|c|c|c|}
\hline Fur Coloration & $\begin{array}{c}\text { Compared } \\
\text { Age Categories }\end{array}$ & $Z$-value & P-value \\
\hline \multirow{3}{*}{ Normal } & $\begin{array}{l}\text { Juvenile with } \\
\text { Subadult }\end{array}$ & -1.60 & 0.1096 \\
\hline & $\begin{array}{c}\text { Subadult } \\
\text { with Adult }\end{array}$ & -2.05 & 0.0405 \\
\hline & $\begin{array}{c}\text { - Juvenile with } \\
\text { Adult }\end{array}$ & -3.52 & 0.0004 \\
\hline \multirow{3}{*}{ Melanistic } & $\begin{array}{c}\text { Juvenile with } \\
\text { Subadult }\end{array}$ & 1.19 & 0.2352 \\
\hline & $\begin{array}{c}\text { Subadult } \\
\text { with Adult }\end{array}$ & 2.36 & 0.0183 \\
\hline & $\begin{array}{c}\text { Juvenile with } \\
\text { Adult }\end{array}$ & 3.40 & 0.0007 \\
\hline \multirow{3}{*}{ Other } & $\begin{array}{c}\text { Juvenile with } \\
\text { Subadult }\end{array}$ & 0.80 & 0.4231 \\
\hline & $\begin{array}{c}\begin{array}{c}\text { Subadult } \\
\text { with Adult }\end{array} \\
\end{array}$ & 0.19 & 0.8465 \\
\hline & $\begin{array}{l}\text { Juvenile with } \\
\text { Adult }\end{array}$ & 1.06 & 0.2885 \\
\hline
\end{tabular}


Table 15. Frequencies of Marmots in Areas Just Previous to Snow Melt and Several Weeks After Snow Melt

\begin{tabular}{|c|c|c|c|c|}
\hline & Lower Garnet Trail & $\begin{array}{c}\text { Lower Death } \\
\text { Canyon }\end{array}$ & $\begin{array}{c}\text { NF Cascade } \\
\text { Canyon }\end{array}$ & Total \\
\hline $\begin{array}{c}\text { Previous to Snow } \\
\text { Melt }\end{array}$ & 16 & 20 & 33 & 69 \\
\hline After Snow Melt & 4 & 8 & 7 & 19 \\
\hline Total & 20 & 28 & 40 & 88 \\
\hline
\end{tabular}

